\title{
Immediate administration of COX inhibitors in spinal cord contusion injury and a current review of COX Therapy
}

\author{
Patrick M Moran ${ }^{1}$, Emmanuel Sampene ${ }^{2}$, Steven G Oakes ${ }^{*}$, Gurwattan S Miranpuri ${ }^{3}$ and Daniel K Resnick $^{3}$ \\ ${ }^{1}$ School of Pharmacy, University of Wisconsin, USA \\ ${ }^{2}$ Department of Biostatistics and Medical Informatics, University of Wisconsin, USA \\ ${ }^{3}$ Department of Neurological Surgery, University of Wisconsin School of Medicine and Public Health, USA
}

\begin{abstract}
Background: Neuropathic pain (NP) is a common complication during the late phase of spinal cord injury (SCI). The enzyme cyclooxygenase-2 (COX-2) shown to play a crucial role during the inflammatory early phase of SCI. We report here on the antihyperalgesic effects of three COX inhibitors: celecoxib, indomethacin and meloxicam used individually. Their efficacy and impact on mortality losses following administration of each treatment evaluated in the late phase of chronic NP post SCI.

Methods: In two studies, 200 Sprague-Dawley rats $(\mathrm{n}=80 ; \mathrm{n}=120)$ received contusion spinal cord injury (cSCI). In study 1, injured rats were administered with either celecoxib ( $\mathrm{n}=20) 12 \mathrm{mg} / \mathrm{kg}$ oral gavage (o.g.) or vehicle (saline only) o.g. ( $\mathrm{n}=20)$; indomethacin ( $\mathrm{n}=20) 5 \mathrm{mg} / \mathrm{kg}$ or vehicle (saline only) (n=20) intraperitoneally (i.p.) for 14 days. In study 2, injured rats received meloxicam either $1 \mathrm{mg} / \mathrm{kg}(\mathrm{n}=20), 2 \mathrm{mg} / \mathrm{kg}(\mathrm{n}=20)$ or $4 \mathrm{mg} / \mathrm{kg}(\mathrm{n}=20)$ i.p. daily for 14 days or vehicle (Saline + DMSO) $(\mathrm{n}=20)$ i.p. daily for 14 days. Also in study 2 injured rats received $30 \mu \mathrm{g} / \mathrm{kg} /$ day $(\mathrm{n}=20)$ or $300 \mu \mathrm{g} / \mathrm{kg} / \mathrm{day}(\mathrm{n}=20)$ intrathecally (i.t.) for 14 days or vehicle $(\mathrm{saline}+$ DMSO) alone delivered i.t. for 7 days. Experimental and control rats were tested for increase or decrease in thermal hyperalgesia (TH) on days $21,28,35$, and 42 after SCI.

Results: In study 1, celecoxib prevented the drop in hyperalgesia threshold and increased the nociceptive threshold compared with control. The percentage of TH observed in celecoxib-treated animals $0.0 \%$ compared to $22.8 \%$ saline- vehicle control group. The percentage of TH observed in indomethacin-treated animals was $19.5 \%$ as compared with the saline-injected control group showing $8.7 \%$, which while reduced, was not significant $(\mathrm{p}=0.7574)$. The rat mortality observed with the treatments of celecoxib o.g. and indomethacin i.p. were $55 \%$ and $35 \%$, respectively. The control group mortality for saline o.g. and saline i.p. was $15 \%$ and $5 \%$, respectively. In study 2, i.t. delivery of meloxicam, exhibited 30\%,33\%, and $67 \%$ in TH development in low dose, high dose, and saline group, respectively. Low dose meloxicam was associated with a reduced $50 \%$ mortality rate as opposed to the $70 \%$ mortality rate for both high dose meloxicam and saline. In study 2 , i.p. delivery of Meloxicam exhibited 0\%, 14.3\%, 47.6\%, 61.9\% TH development for saline, $1 \mathrm{mg} / \mathrm{kg}, 2 \mathrm{mg} / \mathrm{kg}$, and $4 \mathrm{mg} / \mathrm{kg}$ groups respectively. An ANOVA model showed an overall statistically significance difference among the groups ( $\mathrm{p}=0.0129$ ). Rat mortality observed for meloxicam i.p. was $0 \%, 14.29 \%, 47.6 \%$ and $61.95 \%$ for saline, $1 \mathrm{mg} / \mathrm{kg}$, $2 \mathrm{mg} / \mathrm{kg}$, and $4 \mathrm{mg} / \mathrm{kg}$ groups respectively. TH percentages taken as averages from days $21,28,35$, and 42 following SCI.

Conclusion: These results suggest that indomethacin, a nonselective COX inhibitor, given systemically did not statistically decrease pain sensation or increase animal survival. The COX-2 inhibitor, celecoxib, did significantly decrease pain perception in this model when given systemically. However, the mortality percentage increased by celecoxib administration when compared to saline application. This work is integrated into a review of COX use to treat neuropathic pain.

Meloxicam in both high dose and low dose applied i.t. reduced pain perception. Although mortality reduced by low dose meloxicam, this decrease compared to high dose meloxicam or saline was not significant. Meloxicam i.p. showed a dose dependent increase in both TH development and mortality. This suggests the effective therapeutic dose is less than $1 \mathrm{mg} / \mathrm{kg}$ and research should extend further. It is clear that COX-2 selective agents can decrease pain perception compared to COX-1 blocking agents. However, systemic administration of celecoxib may lead to increased adverse effects. Initial studies with the intrathecal administration of the COX-2 inhibitor meloxicam suggest that further research focused on the variables of treatment doses, route of administration and possible combination of COX-2 blockers with other pain reducing agents is necessary to maximize the therapeutic/adverse effect ratio.
\end{abstract}

\section{Introduction}

Neuropathic pain (NP) following spinal cord injury (SCI) represents a profound clinical problem for which there exist limited effective therapies. Approximately 50-75 percent of patients with SCI experience chronic NP disorders [1-5]. Pain at the level of injury could result from either a central trauma or disease of the peripheral nervous system $[2,6]$. The frequent development of NP considered being among the most debilitating sequelae of acute SCI. The pathogenesis of spinal
Correspondence to: Steven G. Oakes, PhD, University of Wisconsin School of Pharmacy, 777 Highland Ave, Madison, WI 53705-222, USA, E-mail: steven. oakes@wisc.edu

Key words: neuropathic pain, pain threshold, spinal cord injury, COX-inhibitors, therapy, review

Received: August 29, 2017; Accepted: September 23, 2017; Published: September 26, 2017 
cord injury neuropathic pain (SCINP) is not very clear. Employing a rat model of contusion SCI, research in our lab has been focused on the use of cyclooxygenase $2(\mathrm{COX}-2)$ inhibitors during the acute phase of SCI [7]. Chronic phase studies of SCI-induced injuries, reviewed from our lab [8] focused on numerous pathways including the use of peroxisome proliferator-activated receptor (PPAR-gamma) agonists [9] ; COX-2 inhibitors [10,11]; vanilloid-1/ bradykinin-1 receptor antagonists [12]; phosphodiesterase-4 (PDE4) inhibitor, rolipram [13]; cannabinoid (CB1/CB2) receptors [14]; ion channel activity including NKCC1/KCC2 in the development of chronic NP [15-18].

The efficacy of selective COX-2 spinal PGE2 release known to contribute significantly in the induction of hypersensitivity of nociceptors and dorsal horn neurons $[19,20]$. Our early studies reported an up-regulation of COX-2 mRNA expression during the acute phase of SCI in rats [7]. Consequently, functional improvement in hind limbs, using a selective COX-2 inhibitor, SC58125 (1-[4-methylsufonyl) phenyl]-3-tri-fluro-methyl-5-[(4-fluro) phenyl] prazole were observed [7]. Pain profile improvements following application of COX-2 inhibitors reducing PGE2 production in numerous studies have been reported [19-22]. Because SCI may cause a relatively immediate increase in PGE2 levels, it is important to consider the possible role of COX-2 induction in the onset of SCI-induced NP. It is clear that COX pathway leads to the formation of eicosanoids including PGE2 [23] and the enhanced eicosanoids have been observed in various pathological processes in the CNS such as SCI [24].

Several non-steroidal anti-inflammatory drugs (NSAIDs) used in the past as non-selective COX inhibitors, and these treatments resulted in gastric/intestinal ulceration [25]. An evidence-based evaluation of the gastrointestinal safety of coxibs has described where selective COX-2 inhibitors prevent this side effect [26]. In clinical trials, use of celecoxib induces very few gastrointestinal complications compared to conventional and non-selective NSAIDs. However, the disorders associated with NSAIDs such as late pregnancy, aspirin-induced asthma, congestive heart failure and renal dysfunction applies to the COX-2 inhibitors [25]. The clinical usefulness of celecoxib has increased in various inflammatory disease states and pain disorders [25].

The COX-2 selective inhibitor, celecoxib, has analgesic and antiinflammatory effects in patients with rheumatoid arthritis but has no effect on COX-1 activity at therapeutic plasma concentrations [27-29]. Celecoxib reduction of early inflammatory responses leads to improved responses in carrageenan-induced paw hyperalgesia and edema [30].

Interestingly, the nonselective COX inhibitor, indomethacin, produced similar results to those seen with celecoxib $[29,30]$. The nonselective COX inhibitor, meloxicam, has been reported to actually show preference for COX-2 inhibition [29]. Meloxicam provides similar anti-inflammatory and analgesic effects to that of nonselective NSAIDs but with a lower gastrointestinal bleeding risk and less effect on platelet aggregation [31]. In a central neuropathic pain model treatment with meloxicam i.t. infusion started immediately after spinal nerve ligation controlled the development of mechanical allodynia and thermal hyperalgesia. However, treatment started a week after nerve ligation could not reverse established NP [32]. Meloxicam administration shown to reduce SCI-induced oxidative stress, exert neural protection by inhibiting lipid peroxidation, deplete GSH, cause DNA fragmentation, and to improve the impairment of the neurological functions due to SCI [33].

The inflammatory response identified as a key mediator of secondary damage following acute SCI, may play a significant role in the pathogenesis of SCI-induced chronic NP syndromes. Potential therapeutic agents evaluated for the treatment of NP throughout SCI. We present data on the efficacy and limitations of three COX inhibitors therapy, celecoxib, indomethacin and meloxicam, administered immediately following SCI.

\section{Materials and methods}

\section{Animals}

Two hundred male Sprague-Dawley rats used for these two studies. The rats weighed between 275 and 300 grams at the time of surgery. Animal care performed in compliance with the published National Institutes of Health guidelines. The protocol and all surgical procedures were in accordance with NIH guidelines and approved by the Institutional Animal Use and Care Committee of the University of Wisconsin.

\section{Spinal cord injury}

Rats were anesthetized using inhalation anesthetic (Isoflurane 5\% for induction and $2 \%$ for maintenance along with oxygen and nitrous oxide in a 1:1 mixture).

Study 1: For celecoxib and indomethacin administration experiments, each animal received a contusion SCI ( $\mathrm{cSCI}$ ) at the T9 level using the New York University (NYU) impactor by dropping a 10 gram rod from $12.5 \mathrm{~mm}$ an established contusion SCI and NP rat model $[9,12-15,17,34-36]$.

Study 2: For meloxicam administration, a T9 and L1 laminectomy performed on a warming pad and a catheter was introduced i.t. at L1 and advanced cranially to T9. The protocol and all surgical procedures were in accordance with NIH guidelines and approved by the UW Institutional Animal Use and Care Committee (ACUC).

\section{Drug administration}

Study 1: Immediately following T9 laminectomy and cSCI, rats received celecoxib $(12 \mathrm{mg} / \mathrm{kg}$, o.g., $\mathrm{n}=20)$ or indomethacin $(5 \mathrm{mg} / \mathrm{kg}$; i.p, $\mathrm{n}=20$ ) for 14 days. Parallel controls were maintained using i.p. or o.g. routes of saline administration $(\mathrm{n}=20$ each).

Study 2: Following T9 and L1 laminectomy rats received cSCI and underwent placement of a mini-osmotic pump filled with either a high $(300 \mu \mathrm{g} / \mathrm{kg} / \mathrm{day} ; \mathrm{n}=20)$ or low $(30 \mu \mathrm{g} / \mathrm{kg} / \mathrm{day} ; \mathrm{n}=20)$ concentration of meloxicam to be delivered at a rate of $1 \mu \mathrm{L} / \mathrm{h}$ for 14 days. The tubing was inserted i.t. (along the spinal cord) at L1 to end just below the injury site at $\mathrm{T} 9$ and pump placed subcutaneously. Control rats $(\mathrm{n}=20)$ underwent placement of a mini-osmotic pump in a similar fashion to the meloxicam treatment group and received saline for 7 days. Following the placement of the pumps, the incisions and skin closed with sutures. The i.t. pump and catheters removed on day 7 and 14 post-injury. In another set of experiment SCI rats were administered $1 \mathrm{mg} / \mathrm{kg}(\mathrm{n}=20)$, $2 \mathrm{mg} / \mathrm{kg}(\mathrm{n}=20), 4 \mathrm{mg} / \mathrm{kg}(\mathrm{n}=20)$ of meloxicam i.p. and compared with i.p. injected vehicle (Saline: DMSO; $1: 1 ; n=20$ ) controls. All animals in different treatment groups in study 1 and 2 received prophylactic antibiotic therapy (cefazolin, $50 \mathrm{mg} / \mathrm{kg} /$ day subcutaneous) for 7 days following SCI.

\section{Thermal hyperalgesia (TH) pain test}

Studies 1 and 2: Rats evaluated for hyperalgesia by the Hargreaves hind limb withdrawal latency test to thermal noxious stimulus. This test is being routinely employed in our SCI/NP rat model in our lab $[12-15,17,37]$. An animal placed inside a plastic box on a raised glass 
surface. A movable focused beam of radiant heat placed under the animal's paw and a timer started. The beam turns off as soon as the animal moved its paw. The latency for the animal (in seconds) to withdraw its paw was recorded on a day before SCI (day 0 ) as baseline data followed by on days 21, 28, 35, 42 after SCI. Hyperalgesia was defined only in animals exhibiting a decrease in withdrawal latency time (WLT) relative to baseline of $\geq 3$ seconds.

\section{Health and mortality of treated rats}

Post-care treated animals checked twice a day for health status and mortality. Rats underwent manual expression of urine for twice a day for a week. Dead rats taken to the Comparative Pathology Laboratory, Research Animal Resources Center (RARC) at University of Wisconsin, Madison. Histopathology check included kidney, salivary gland, thymus, pancreas, spleen, preputial gland, adrenal glands, thyroid gland, liver, bladder, male urogenital tract, heart, lung, mesenteric lymph nodes, GI tract, stomach, brain, eyes, and spinal cord.

\section{Statistical considerations}

Descriptive statistics, including means and standard deviations for continuous variables and frequencies for categorical variables, were reported for Studies 1 and 2. For study 1, a simple t-test was used to compare OG saline to OG celecoxib and IP saline to IP indomethacin. For the thermal hyperalgesia $(\mathrm{TH})$ pain experiment, a t-test was also used to compare the groups of OG saline to OG celecoxib and IP saline to IP indomethacin.

In study 2, the withdrawal latency time (WLT) and TH outcomes was assessed using a one-way analysis of variance (ANOVA) model, where the null hypothesis that the group means of IP saline, IP meloxicam $1 \mathrm{mg} / \mathrm{kg}$, IP meloxicam $2 \mathrm{mg} / \mathrm{kg}$ and IP meloxicam $4 \mathrm{mg} / \mathrm{kg}$ are equal will be tested globally. If the overall ANOVA model is significant, then we proceeded to perform a post-hoc analysis to ascertain the effects of pairwise comparisons among the groups, using a Tukey's honestly significant difference (HSD) post-hoc test. In addition, we investigated how well the model fits the data by reporting goodness-of-fit statistics, including R-squared measures, which describes the percentage of variation in the response that is explained by the model. Furthermore, for the meloxicam therapy experiments the withdrawal latency time for rats exhibiting thermal hyperalgesia compared to rats not exhibiting thermal hyperalgesia was performed using a simple t-test. All statistical analyses were conducted using the 2-sided alpha significance level of 0.05 , with STATA v15 software.

\section{Results}

\section{Study 1: Celecoxib and indomethacin therapy}

Celecoxib prevented the drop in hyperalgesia threshold and increased the nociceptive pain threshold compared with control, although this increase was not statistically significant $(\mathrm{p}=0.4696)$. Indomethacin treatment showed a decrease in the thermal hyperalgesia threshold, but the decrease is not statistically significant ( $\mathrm{p}=0.7574)$.

Overall, there was no significant difference in TH (WLT) observed in four groups of rats following experimental treatments including controls (Figure 1A,2A). However, there was a statistically significant difference between OG celecoxib compared to OG saline $(\mathrm{p}=0.0204)$, while the comparison between IP indomethacin and IP saline was not statistically significant $(\mathrm{p}=0.2206)$ for the TH variable. Percentage TH observed in celecoxib-treated animals was zero (0) as compared with saline-injected control group showing 22.8 (Figure 1B,1C). Percentage $\mathrm{TH}$ observed in indomethacin-treated animals was 19.5 as compared with saline-injected control group showing 8.7 (Figure 2B,2C).

Percentage mortality in rats treated with celecoxib o.g. injections exhibited $55 \%$ of rat mortality when compared with $15 \%$ in saline o.g. control group (Figure 1D), whereas i.p. administered indomethacin resulted in $35 \%$ mortality as compared with $5 \%$ in control group (Figure 2D) (Table 1).

\section{Study 2: Meloxicam therapy}

Overall, the ANOVA model showed no statistical significance for the WLT variable among the groups $(\mathrm{F}(3,16)=1.4102, \mathrm{p}=0.2075)$. However, looking at the data cross-sectionally, baseline saline i.p WLT was significantly different from saline i.p. WLT on days 21 and 42 . One $\mathrm{mg} / \mathrm{kg}$ meloxicam i.p. treated rats WLT was significantly different from saline i.p. WLT on day $21.2 \mathrm{mg} / \mathrm{kg}$ meloxicam i.p. treated rats WLT was significantly different from saline i.p. WLT on Days 21, 28, and 35. $4 \mathrm{mg} / \mathrm{kg}$ meloxicam i.p. treated rats WLT was significantly different from saline i.p. WLT on Days 21 and 28 (Figures 3A-3C).

The percent of rats exhibiting thermal hyperalgesia averaged from days $21,28,35$, and 42 for saline, $1 \mathrm{mg} / \mathrm{kg}, 2 \mathrm{mg} / \mathrm{kg}, 4 \mathrm{mg} / \mathrm{kg}$ of meloxicam i.p. are 28.8, 41.8, 54.6, and 59.4\%, respectively (Figure 4A). For this analysis, the overall ANOVA model was statistically significant $(\mathrm{F}(3,2)=5.52, \mathrm{p}=0.0129)$, with approximately $58 \%$ of the variance being explained by the model. This means that differences among the groups were detected. In particular, the Tukey's HSD post-hoc test showed that the WLT was statistically significantly higher for IP meloxicam $2 \mathrm{mg} /$ $\mathrm{kg}$ compared to IP saline $(25.78 \pm 8.26, \mathrm{p}=0.038)$. Similarly, statistical significance was observed for IP meloxicam $4 \mathrm{mg} / \mathrm{kg}$ compared to IP saline $(30.61 \pm 8.26, p=0.014)$. However, there was no other significance difference observed for the other group comparisons.

Percentage mortality in different experimental groups of rats including saline control, $1 \mathrm{mg} / \mathrm{kg}, 2 \mathrm{mg} / \mathrm{kg}$ and $4 \mathrm{mg} / \mathrm{kg}$ meloxicam i.p. was $0.0,14.3,47.6$ and 61.9 , respectively (Figure $4 \mathrm{~B}$ ).

Low-dose meloxicam was associated with a reduction in mean shortening of WLT $(\mathrm{sec})$ compared to saline group in rats not

Table 1. Indomethacin IP and Celecoxib OG

\begin{tabular}{|c|c|c|c|c|c|}
\hline Days & 0 & 21 & 28 & 35 & 42 \\
\hline \multicolumn{6}{|c|}{ Withdraw Latency Time (sec) } \\
\hline OG Saline & 9.8 & 8.5 & 8.1 & 8.6 & 9.9 \\
\hline OG Celecoxib & 8.7 & 8.7 & 8.4 & N/A & $\mathrm{N} / \mathrm{A}$ \\
\hline IP Saline & 8.7 & 8.1 & 8.3 & 7.8 & 8.6 \\
\hline IP Indomethacin & 9.2 & 8.0 & 9.1 & 6.8 & 9.2 \\
\hline \multicolumn{6}{|c|}{ Percent Thermal Hyperalgesia (TH) } \\
\hline OG Saline & - & 31.57 & 26.31 & 27.77 & 5.88 \\
\hline OG Celecoxib & - & 0 & 0 & 0 & N/A \\
\hline IP Saline & - & 13.63 & 5.26 & 10.52 & 5.26 \\
\hline IP Indomethacin & - & 25.00 & 0 & 36.36 & 16.66 \\
\hline
\end{tabular}


(A)

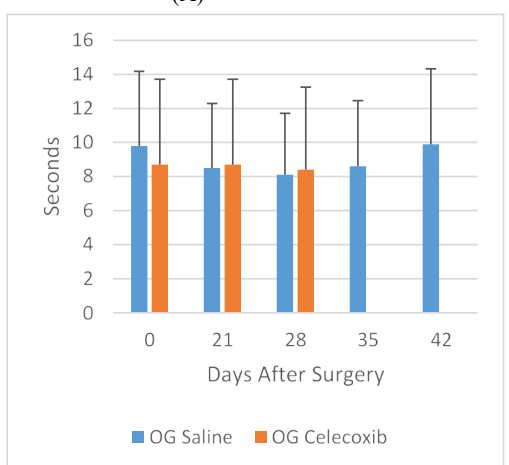

(C)

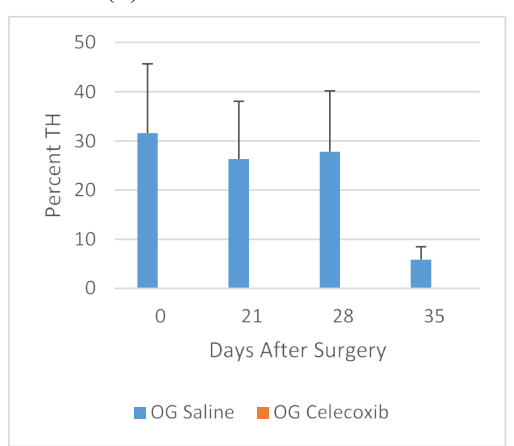

(B)

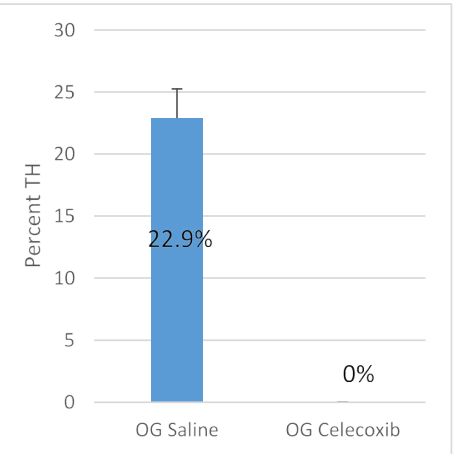

(D)

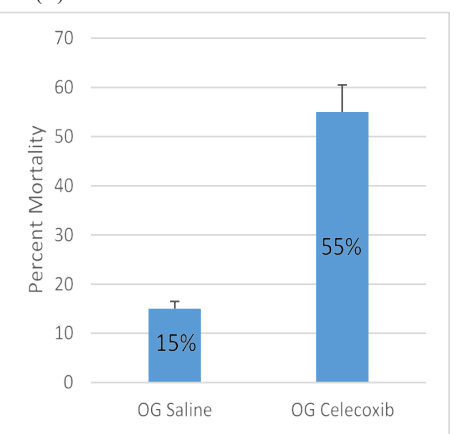

Figure 1. Celecoxib Treatment of SCI Rats

A: Withdraw latency time (sec.) of Celecoxib o.g. and saline o.g. treated rats on days $0,21,28,35,42$ after SCI. Overall, this comparison was statistically significant ( $\mathrm{p}=0.0204$ ) B: Percent TH of saline o.g. and Celecoxib o.g. averaged from days 0,21, 28, 35, 42 after spinal cord injury. C: Percent TH development for Celecoxib o.g. and saline o.g. treated rats on days 21,28 , 35, 42 after SCI. D: Percent mortality for Celecoxib o.g. and saline o.g.

(A)

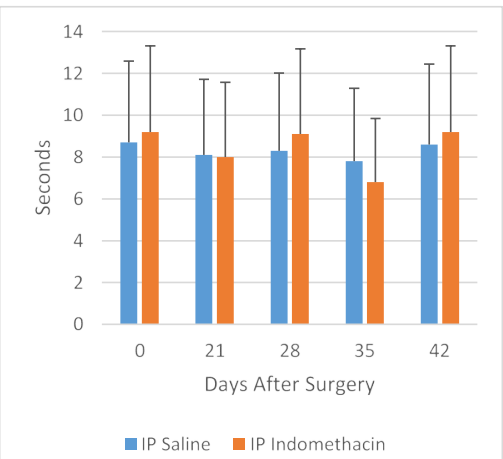

(C)

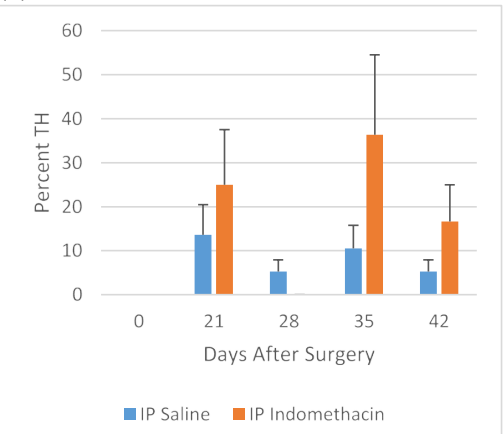

(B)
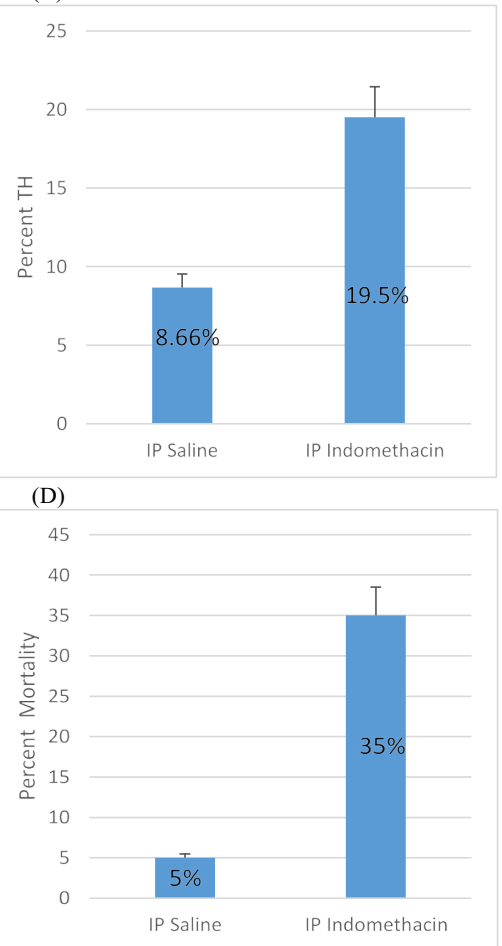

Figure 2: Indomethacin Treatment of SCI Rats

A: Withdraw latency time (sec.) for Indomethacin i.p. and saline i.p. treated rats on days $0,21,28,35,42$ after SCI. Overall, this comparison was not statistically significant ( $\mathrm{p}=0.2206$ ) B Percent TH of saline i.p. and Indomethacin i.p. average from days 0, 21, 28, 35, 42 after spinal cord injury. C: Percent TH development for Indomethacin i.p. and saline i.p. treated rats on days $21,28,35,42$ after SCI. D: Percent mortality for Indomethacin i.p. and saline i.p. 
(A)

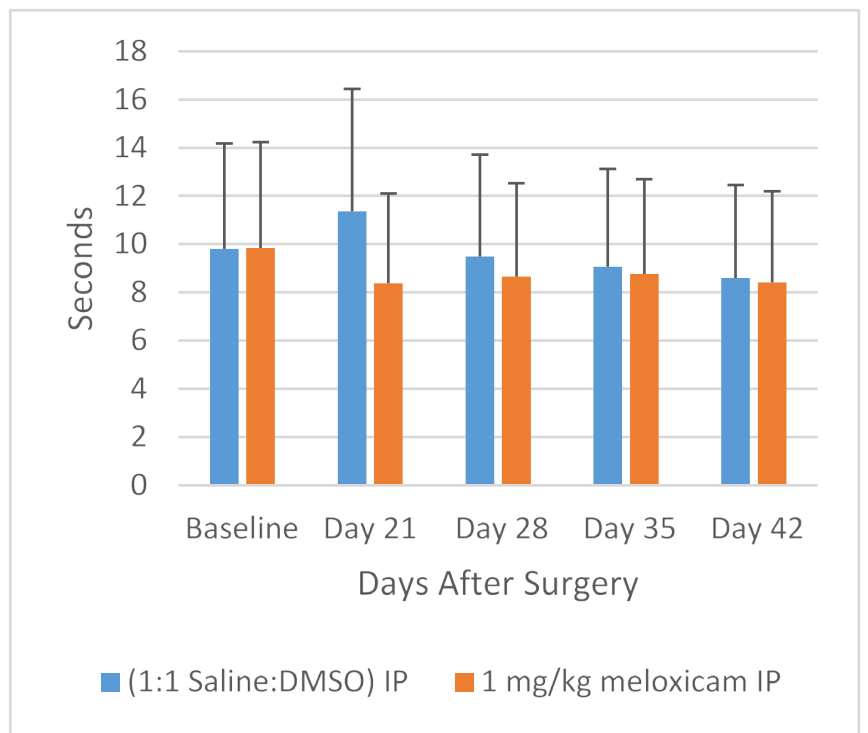

(B)

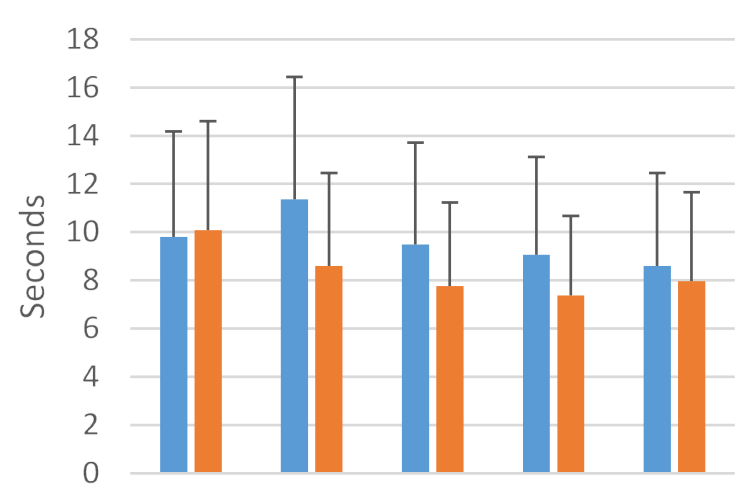

Baseline Day 21 Day 28 Day 35 Day 42

Days After Surgery

" (1:1 Saline:DMSO) IP $\quad 2$ mg/kg meloxicam IP

(C)

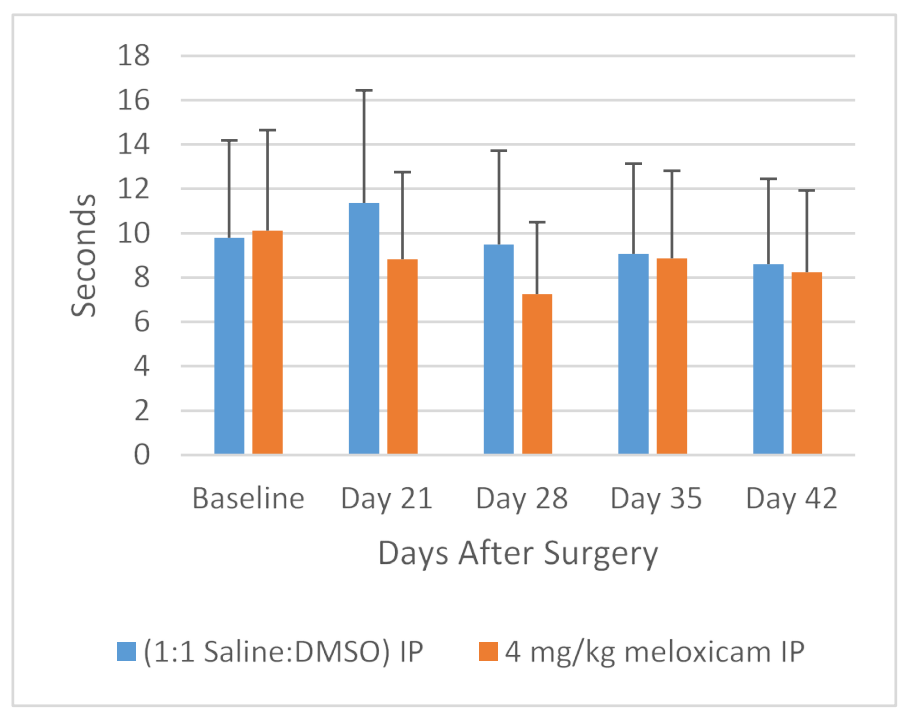

Figure 3: Meloxicam IP Withdraw Latency Times

A: Withdraw latency time (sec.) for rats treated with meloxicam i.p., $1 \mathrm{mg} / \mathrm{kg}$, or saline i.p. on days $0,21,28,35,42$ after SCI. B: Withdraw latency time for rats treated with meloxicam i.p., $2 \mathrm{mg} / \mathrm{kg}$, or saline i.p. on days $0,21,28,35,42$ after SCI. C: Withdraw latency time for rats treated with meloxicam i.p., $4 \mathrm{mg} / \mathrm{kg}$, or saline i.p. on days 0, 21, 28, 35, 42 after SCI.

exhibiting hyperalgesia however this was not statistically significant $(\mathrm{p}=0.0833)$ and the effect did not persist through day 42 (Figure 5B). In animals that exhibited hyperalgesia on day 28 through 42 post-SCI, both low dose and high dose meloxicam treatment transiently reduced the severity of hyperalgesia by increasing WLT, but this effect did not persist through day 42 and was not significant. (Figure 5A).

Among the animals that completed the study following i.t. delivery, both low- and high-dose meloxicam treatments were associated with a reduced rate of TH development, $30 \%$ in high-dose, $33 \%$ in low-dose as compared with $67 \%$ in saline as vehicle alone. (Figure 5C).

Percentage mortality in rats infused intrathecally with saline, meloxicam high- and low- dose was 70, 70, and 50, respectively (Figure 5D) (Table 2,3).

\section{Histopathology diagnosis of rats necropsy}

The following histopathology reports by Dr. Ruth Sullivan, Diplomate, American College of Veterinary pathologists, represent the mortality among rats treated with meloxicam $4 \mathrm{mg} / \mathrm{kg}$ body weight. In summary, these observations from two rats are included in Table 4.

\section{Discussion}

\section{Study 1: Indomethacin and celecoxib}

Celecoxib current findings: Celecoxib recognized as a selective COX-2 inhibitor [25]. COX-2 after induction peripherally, and within the CNS, plays significant role in producing inflammatory pain, but controversial in neuropathic pain [38]. Overall, our findings show no 
Table 2. Meloxicam IP

\begin{tabular}{|c|c|c|c|c|c|}
\hline Days & Baseline & 21 & 28 & 35 & 42 \\
\hline \multicolumn{6}{|c|}{ Withdraw Latency Time (sec) } \\
\hline IP Saline & 9.80 & 11.36 & 9.48 & 9.07 & 8.60 \\
\hline IP Meloxicam $1 \mathrm{mg} / \mathrm{kg}$ & 9.84 & 8.37 & 8.65 & 8.77 & 8.42 \\
\hline IP Meloxicam 2 mg/kg & 10.09 & 8.60 & 7.76 & 7.37 & 7.96 \\
\hline IP Meloxicam 4 mg/kg & 10.12 & 8.82 & 7.25 & 8.86 & 8.24 \\
\hline \multicolumn{6}{|c|}{ Percent Thermal Hyperalgesia (TH) } \\
\hline IP Saline & - & 18.75 & 29.41 & 29.41 & 37.50 \\
\hline IP Meloxicam $1 \mathrm{mg} / \mathrm{kg}$ & - & 42.86 & 35.71 & 35.71 & 53.85 \\
\hline IP Meloxicam $2 \mathrm{mg} / \mathrm{kg}$ & - & 54.55 & 72.73 & 45.45 & 45.45 \\
\hline IP Meloxicam 4 mg/kg & - & 62.50 & 75.00 & 37.50 & 62.50 \\
\hline
\end{tabular}

(A)

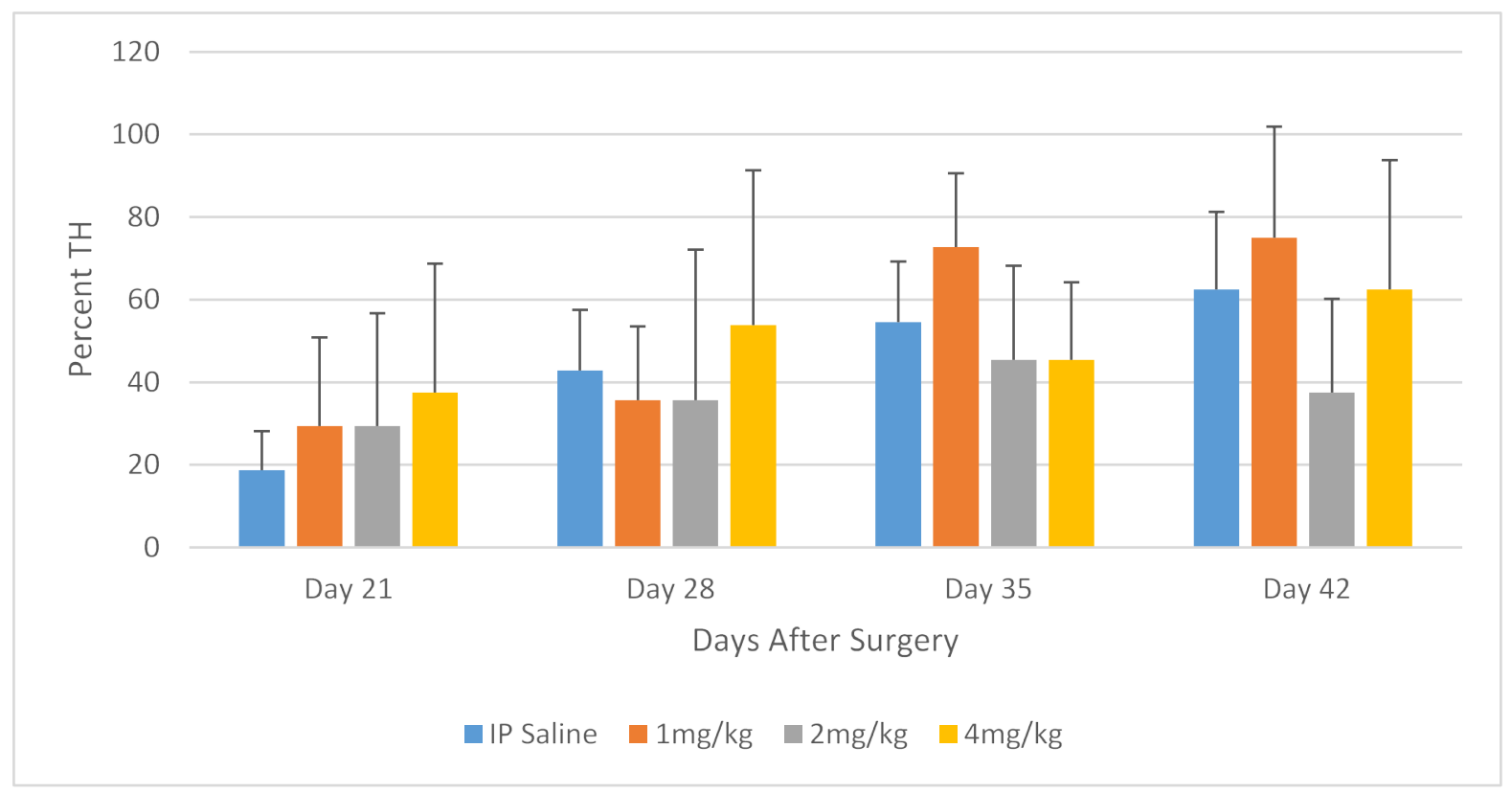

(B)

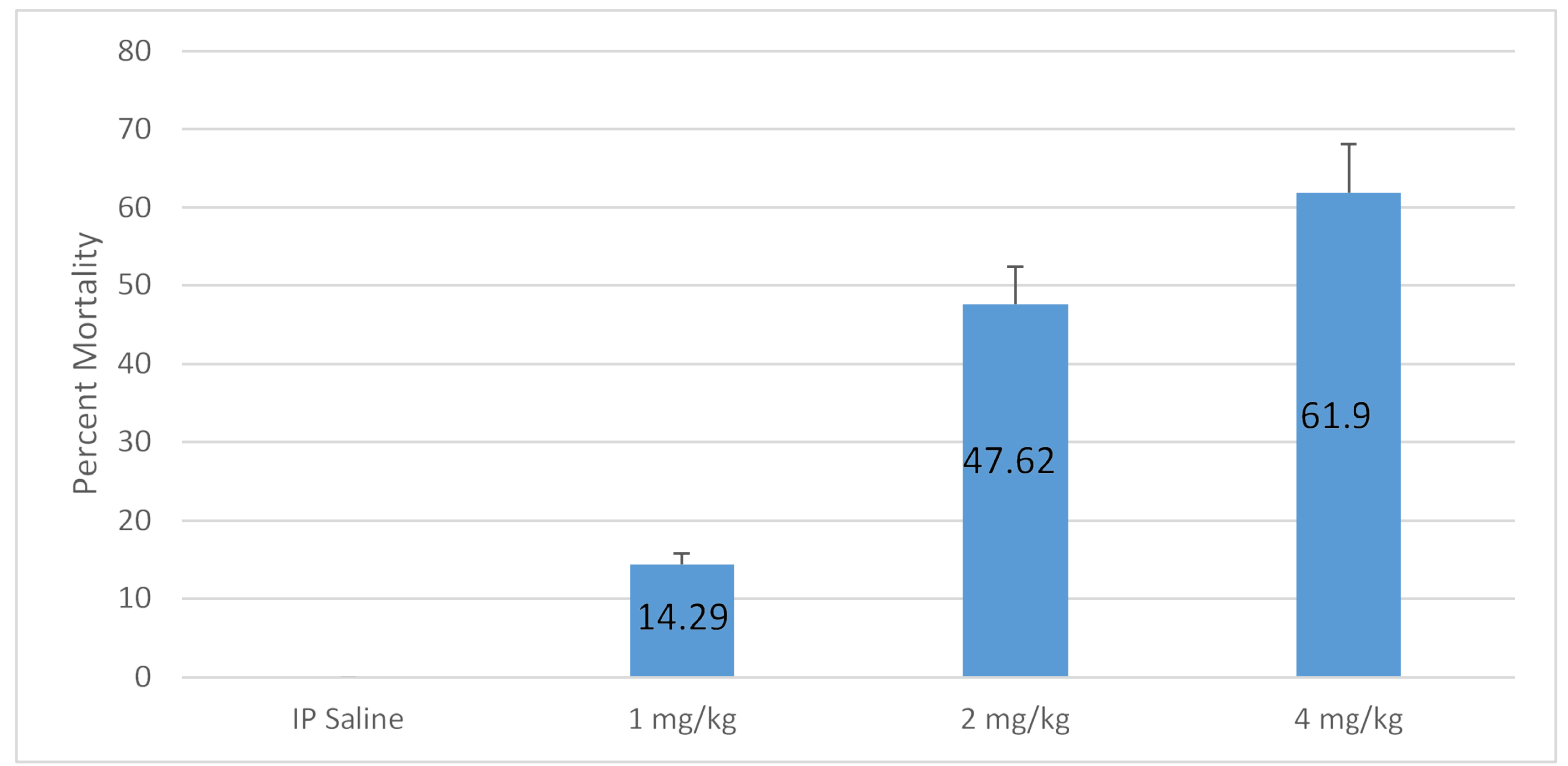

Figure 4: Meloxicam IP Thermal Hyperalgesia and Mortality

A: Percent TH development for rats treated with Meloxicam i.p. (1mg/kg, $2 \mathrm{mg} / \mathrm{kg}$, and $4 \mathrm{mg} / \mathrm{kg}$ ), or saline i.p. on days $21,28,35,42$ after SCI. B: Percent mortality for rats treated with Meloxicam i.p. $(1 \mathrm{mg} / \mathrm{kg}, 2 \mathrm{mg} / \mathrm{kg}$, and $4 \mathrm{mg} / \mathrm{kg})$, or saline 
Table 3. Meloxicam IT

\begin{tabular}{|c|c|c|c|c|}
\hline Days & Baseline & 28 & 35 & 42 \\
\hline \multicolumn{5}{|c|}{$\begin{array}{l}\text { Withdraw Latency Time (Sec) Rats } \\
\text { Exhibiting TH }\end{array}$} \\
\hline IT Saline & 10.1 & 8.4 & 7.4 & 10.4 \\
\hline $\begin{array}{l}\text { IT Meloxicam } \\
\text { High Dose }\end{array}$ & 12.3 & 9.5 & 9.9 & 6.9 \\
\hline $\begin{array}{l}\text { IP Meloxicam } \\
\text { Low Dose }\end{array}$ & 11.1 & 8.6 & 9.2 & 7.5 \\
\hline \multicolumn{5}{|c|}{$\begin{array}{l}\text { Withdraw Latency Time (sec) Rats } \\
\text { Not Exhibiting TH }\end{array}$} \\
\hline IP Saline & 8.4 & 7.9 & 11.2 & 13.7 \\
\hline $\begin{array}{l}\text { IP Meloxicam } \\
\text { High Dose }\end{array}$ & 10.7 & 10.0 & 10.0 & 10.2 \\
\hline $\begin{array}{l}\text { IP Meloxicam } \\
\text { Low Dose }\end{array}$ & 9.8 & 10.8 & 11.2 & 11.1 \\
\hline
\end{tabular}

Table 4. Histopathology diagnosis of rats necropsy

\begin{tabular}{|c|c|}
\hline Rat \#1 & \\
\hline Kidney & $\begin{array}{l}\text { Renal tubular regeneration, suggestive of mild chronic } \\
\text { nephropathy of the rat, mild to moderate }\end{array}$ \\
\hline Lymph node & $\begin{array}{l}\text { Lymph node (lymphoid depletion, marked, mandibular } \\
\text { lymph node);. }\end{array}$ \\
\hline Mediastinal lymph node & Multifocal acute hemorrhage) \\
\hline Thymus & $\begin{array}{l}\text { Lymphoid necrosis, minimal to mild; multifocal modest } \\
\text { hemorrhage, acute). }\end{array}$ \\
\hline Preputial gland & Adenitis, suppurative, multifocal, severe \\
\hline Thyroid gland & Degeneration \\
\hline Mesentery & $\begin{array}{l}\text { Superficial fibrosis with reactive mesothelial cells } \\
\text { and mild lymphocytic inflammation, suggestive of } \\
\text { chronic fibro sing peritonitis, with occasional minimal } \\
\text { neutrophilic infiltration }\end{array}$ \\
\hline Stomach & $\begin{array}{l}\text { Gastric erosion with presumptive hemorrhage, } \\
\text { multifocal, moderate. }\end{array}$ \\
\hline Body as a Whole & $\begin{array}{l}\text { Vascular collapse, suggested by dilated and congested } \\
\text { blood vessels in brain }\end{array}$ \\
\hline Small intestine & $\begin{array}{l}\text { Segmental complete degeneration of portions of small } \\
\text { intestine, possible autolytic change secondary to } \\
\text { inadequate fixation but possibly occurring in life, given } \\
\text { the overall reasonably good fixation of the majority of } \\
\text { tissues }\end{array}$ \\
\hline Spinal cord & $\begin{array}{l}\text { Myelomalacia, predominantly poliomyelomalacia, with } \\
\text { cavitation and gitter cell infiltration of spinal cord gray } \\
\text { matter, and with multiple swollen axons within white } \\
\text { matter facts }\end{array}$ \\
\hline $\begin{array}{l}\text { Vertebral column and axial } \\
\text { musculature }\end{array}$ & $\begin{array}{l}\text { Focal osteonecrosis with dense fibrous scar formation } \\
\text { and dorsal putative seroma formation with formation } \\
\text { of fibrous pocket with central fibrillar eosinophilic } \\
\text { material, potentially consistent with seroma formation at } \\
\text { the presumed surgical site }\end{array}$ \\
\hline \multicolumn{2}{|l|}{ Rat \#2 } \\
\hline Hemorrhagic enteritis & $\begin{array}{l}\text { Segmental, involving a segment of jejunum;; seroma, } \\
\text { underlying surgical site }\end{array}$ \\
\hline hemorrhagic gastritis & $\begin{array}{l}\text { Locally extensive, involving the glandular portion of } \\
\text { stomach, moderate }\end{array}$ \\
\hline Spinal cord lesion & $\begin{array}{l}\text { With defect in dorsal spinal process of vertebral body } \\
\text { at T9; keratitis and sclerotic with reddened corneas and } \\
\text { sclera, bilateral }\end{array}$ \\
\hline
\end{tabular}

significant difference in withdrawal latency times between control and celecoxib-treated animals (Figure 1A). There was, however, a significant difference in observed thermal hyperalgesia between control and treated animals (Figure 1B). Hyperalgesia was observable in about $28.5 \%$ of the control animals on days 21,28 and 35 and in about $5 \%$ on day 42 (Figure 1C). Celecoxib (12 mg/kg X 14 days) administered by o.g. prevented the appearance of hyperalgesia due to spinal cord injury on days 21,28 and 35 (Figure 1B,1C). Overall mortality was $15 \%$ in the saline o.g. control group compared to $55 \%$ in the celecoxib-treated o.g. group (Figure 1D).
Role of celecoxib in nerve damage models: Currently several COX-2 inhibitors including celecoxib, rofecoxib, and valdecoxib or experimental agents (sc58125, dup 697) sold commercially for various arthritic symptoms. Celecoxib and rofecoxib reported 100 to 1000 times more selective on the COX-2 than on the COX-1 isoform [25]. Use of celecoxib approved in the USA and Europe for osteoarthritis and rheumatoid arthritis in adults [25]. Oral administration of celecoxib been shown to readily distribute to all tissues including the spinal cord in a rat model [39]. Distribution and metabolism of celecoxib in rats is similar to in humans through a single metabolic pathway. Celecoxib has analgesic and anti-inflammatory effects in patients with rheumatoid arthritis and no effect on COX-1 activity at therapeutic plasma concentrations $[25,31,32]$. In past studies, efficacy of several selective COX-2 inhibitors using chemically- and physically-induced peripheral nerve injury in animal research models has been reported.

In carrageenan-induced paw hyperalgesia studies in rats, pretreatment with rofecoxib or celecoxib significantly increased the mechanically-determined hyperalgesia threshold due to inflammatory responses in the initial 24 hour period post nerve injury [30]. Intraperitoneal administration of the experimental selective COX-2 inhibitor dup 697 to rats with Carrageenan-induced paw hyperalgesia resulted in a significant decrease in mechanical hyperalgesia [40]. However, it was also shown that dup 697 potentiated COX-2 mRNA induction in the lumbar of the spinal cord indicating that there may be a regulatory mechanism with the ability to overcome COX-2 inhibition [40]. In a similar study on rats with carrageenaninduced paw hyperalgesia, daily treatment with the COX-2 selective inhibitors celecoxib, nimisulide, and aceclofenac for 2 weeks, resulted in attenuated thermal hyperalgesia [41]. The experimental COX-2 inhibitor sc58125 was administered IT or IP to carrageenan-induced paw hyperalgesia rats either 10 minutes before or 170 minutes after induction of hyperalgesia [28]. Pretreatment of the inhibitor both systemically and spinally blocked initial development of thermal hyperalgesia. However only systemic administration of the drug was shown to reduce established thermal hyperalgesia suggesting that spinal COX-2 is necessary for initiation of thermal hyperalgesia while nonspinal synthesis of prostanoids by COX enzyme are responsible for the maintenance of thermal hyperalgesia along with tissue inflammation and damage [28]. The effects of celecoxib given orally to diabetic rats when a $0.5 \%$ formalin test was administered orally 30 minutes before formalin injection reduced pain and showed antihyperalgesic effects in both diabetic and non-diabetic rats [42]. This provides evidence for coxibs use as a therapeutic agent to alleviate neuropathic pain in diabetic patients [42].

Rofecoxib treatment ( 1 and $3.2 \mathrm{mg} / \mathrm{kg}$ for 5 and 3 days respectively starting on the day of surgery) failed to modify the development of allodynia and hyperalgesia in the SNI model (sciatic nerve ligation) [38]. This suggests that pain hypersensitivity in the periphery may not be completely COX-2 dependent [38]. Neuropathic pain induced by chronic constriction injury to the sciatic nerve was attenuated by treatment with celecoxib $(30 \mathrm{mg} / \mathrm{kg}$ daily for 14 days starting 3 days after surgery) [43]. These studies report that Celecoxib and other selective COX-2 inhibitors have been effective in reducing hyperalgesia and allodynia in the periphery of chemically induced pain. Studies with mechanically induced peripheral neuropathic pain, a more relevant clinical model, have not been as extensively investigated and the efficacy of selective COX-2 inhibitors in this model to reduce hyperalgesia and allodynia are less clear. Furthermore, the ability of selective COX-2 inhibitors to alleviate mechanically induced neuropathic pain to the central nervous system have yet to be investigated. 
(A)

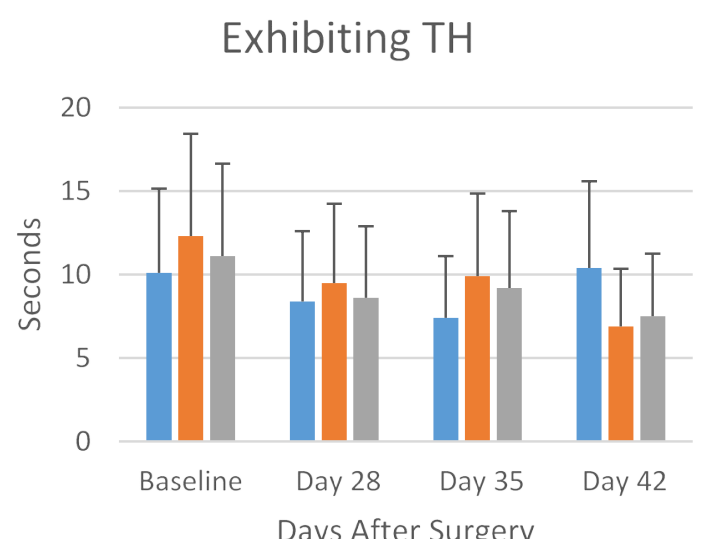

- IT Saline

- IT Meloxicam High Dose

IT Meloxicam Low Dose

(C)

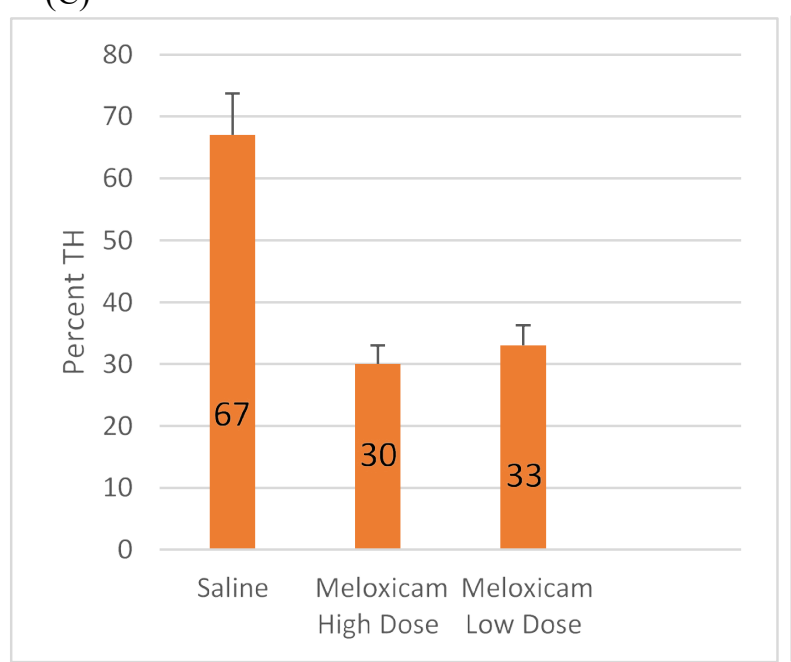

(B)

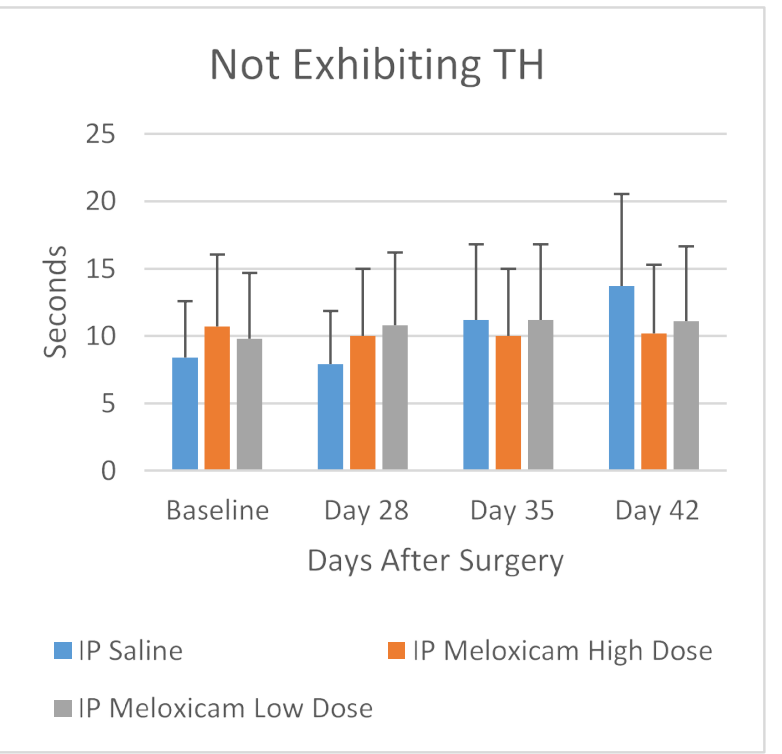

(D)

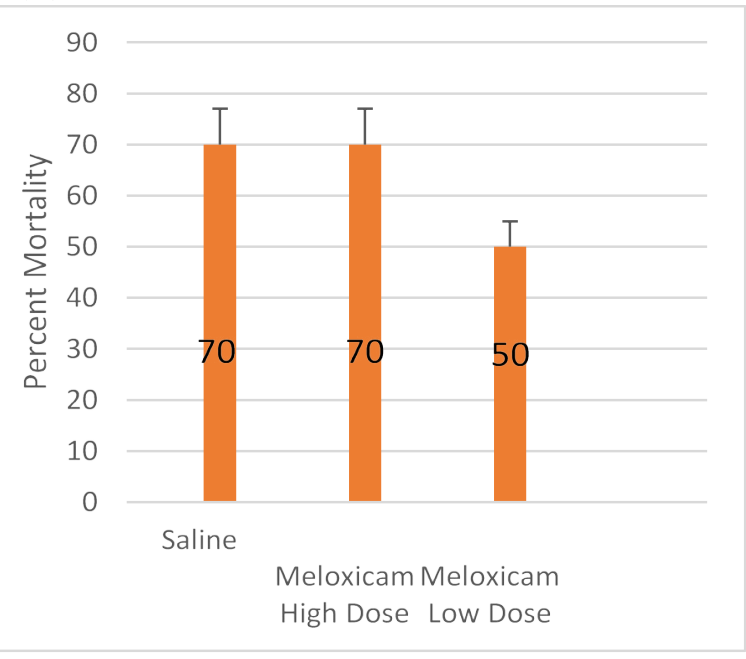

Figure 5: Meloxicam IT Treatment SCI Rats

A: Withdraw latency times (sec) for meloxicam i.t. (low dose, high dose) and saline i.t. for rats exhibiting TH on days $0,28,35,42$ after SCI. B: Withdraw latency times (sec.) for meloxicam i.t. (low dose, high dose) and saline i.t. for rats not exhibiting TH on days 0, 28, 35, 42 after SCI. C: Percent TH developed for meloxicam i.t. (low dose, high dose) and saline i.t. treated rats

Indomethacin current findings: Indomethacin is described as a nonselective COX inhibitor showing preference for the inhibition of COX-1 [29]. There was no significant difference in withdrawal latency times between control and indomethacin-treated animals (Figure 2A). There was also no significant difference in observed thermal hyperalgesia between control and treated animals (Figure 2B). Hyperalgesia was observable in about $9 \%$ of the control animals on days $21,28,35$ and day 42 . Indomethacin administered i.p. $(5 \mathrm{mg} / \mathrm{kg}$ X 14 days) increased the incidence of hyperalgesia by $19.5 \%$ but the change was not significant (Figures 2B,2C). Substantial mortality was observed in different experimental groups. Overall mortality was $5 \%$ in the saline i.p. control group compared to $35 \%$ in the indomethacintreated 1.p.group (Figure 2D).

Role of indomethacin in nerve damage models: The non-selective COX-2 inhibitors such as indomethacin and ibuprofen are used extensively in the clinical setting to reduce general systemic pain and inflammation [44]. However, their therapeutic value of attenuating neuropathic pain in still being evaluated. In past studies using an animal model, the efficacy of several non-selective COX inhibitors used in both chemically- and physically-induced peripheral nerve injury and physically-induced central nerve injury have been reported.

In carrageenan-induced paw hyperalgesia and edema study, pretreatment of non-selective COX-2 inhibitors indomethacin and Piroxicam failed to increase the nociceptive threshold after 24 hours while COX-2 selective inhibitors rofecoxib and celecoxib increased the mechanically-determined hyperalgesia threshold [30]. It was concluded that hyperalgesia is expressed only over a critical range of COX-2 inhibition and that concomitant inhibition of COX-1 prevents the increase in hyperalgesia threshold [30]. In a different study [41] the non-selective COX-2 inhibitors ibuprofen and indomethacin were administered IP for 2 weeks to rats with carrageenan induced hyperalgesia. Results from the study showed that both of the nonselective inhibitors were ineffective in reducing thermal hyperalgesia. 
Table 5. Literature Review

\begin{tabular}{|c|c|c|c|c|c|c|c|}
\hline Author & Animal/Species & Pain Model & Drug/Dose & Delivery & $\begin{array}{l}\text { Time of Drug } \\
\text { Administration }\end{array}$ & Duration of Study & Results \\
\hline \multicolumn{8}{|c|}{ Peripheral Nervous System } \\
\hline$[40]$ & $\begin{array}{l}\text { Male Glaxo-bred } \\
\text { random hooded rats }\end{array}$ & $\begin{array}{l}\text { Carrageenan induced } \\
\text { hyperalgesia. }\end{array}$ & $\begin{array}{l}\text { Cox-2 selective } \\
\text { inhibitor coxib (DuP } \\
697): 10 \mathrm{mg} / \mathrm{kg}\end{array}$ & I.P. & $\begin{array}{l}\text { (Dup 697) Coxib } \\
\text { administered at same } \\
\text { time as carrageenan } \\
\text { induced pain. }\end{array}$ & $\begin{array}{l}\text { Mechanical } \\
\text { hyperalgesia } \\
\text { measured } 4 \text { hours } \\
\text { after pain induction }\end{array}$ & $\begin{array}{l}\text { Treatment of rats with } \\
\text { Dup } 697 \text { coxib caused } \\
\text { significant decrease } \\
\text { in mechanical } \\
\text { hyperalgesia when } \\
\text { compared to saline } \\
\text { treated rats. }\end{array}$ \\
\hline$[28]$ & $\begin{array}{l}\text { Male Holtzman } \\
\text { Sprague-Dawley }\end{array}$ & $\begin{array}{l}\text { Carrageenen induced } \\
\text { Thermal Hyperalgesia }\end{array}$ & $\begin{array}{l}\text {-Coxib (SC58125): } 1 \text {, } \\
10,30 \mathrm{mg} / \mathrm{kg} \text { I.P. and } \\
50 \mathrm{nmol} \mathrm{I.T.} \\
\text {-Ibuprofen } 1,10,30 \\
\text { mg/kg I.P. and } 80 \\
\text { nmol I.T. }\end{array}$ & I.T or I.P. & $\begin{array}{l}\text {-Group } 1 \text { given } \\
\text { I.P and I.T.drug } \\
\text { treatments } 170 \text { min } \\
\text { after carrageenen } \\
\text { induced thermal } \\
\text { hyperalgesia. } \\
\text {-Group } 2 \text { given } \\
\text { I.P and I.T drug } \\
\text { treatments } 10 \text { minutes } \\
\text { before Carrageenan } \\
\text { induced TH. }\end{array}$ & $\begin{array}{l}\text { Thermal hyperalgesia } \\
\text { was assessed every } \\
30 \text { min for } 240 \text { min, } \\
\text { starting } 60 \text { min after } \\
\text { carrageenan injection. }\end{array}$ & $\begin{array}{l}\text { Pretreatment of } \\
\text { both drugs blocked } \\
\text { initial TH when } \\
\text { administered } \\
\text { either spinally } \\
\text { or systemically. } \\
\text { Established TH } \\
\text { (170 days) only } \\
\text { reversed by systemic } \\
\text { administration of both } \\
\text { drugs. }\end{array}$ \\
\hline$[30]$ & $\begin{array}{l}\text { Male Holtzman } \\
\text { Sprague-Dawley rats }\end{array}$ & $\begin{array}{l}\text { Carrageenan induced } \\
\text { Hyperalgesia }\end{array}$ & $\begin{array}{l}\text {-Celecoxib 3,6,12,30 } \\
\mathrm{mg} / \mathrm{kg} \mathrm{SC} \text {; } \\
300 \mu \mathrm{g} \mathrm{I.Pl} . \\
\text {-Rofecoxib .35, .7, } \\
\text { 1.4, 3.5 mg/kg S.C. } \\
\text {-Indomethacin .5 } \\
\mathrm{mg} / \mathrm{kg} \\
\text {-Piroxicam } \\
\quad 3,20 \mathrm{mg} / \mathrm{kg}\end{array}$ & $\begin{array}{l}\text { S.C. } \\
\text { Intraplantar (I.P1.) }\end{array}$ & $\begin{array}{l}\text { Given } 30 \text { minutes } \\
\text { before carrageenan } \\
\text { induced hyperalgesia. }\end{array}$ & $\begin{array}{l}\text { Mechanical } \\
\text { hyperalgesia assessed } \\
1,2,3,4, \text { and } 24 \text { hours } \\
\text { after carrageenan } \\
\text { induced hyperalgesia. }\end{array}$ & $\begin{array}{l}\text { Celecoxib and } \\
\text { Rofecoxib S.C. as } \\
\text { well as Celecoxib } \\
\text { I.Pl. Abolished } \\
\text { hyperalgesia and } \\
\text { induced hypoalgesia. } \\
\text { Indomethacin and } \\
\text { piroxicam abolished } \\
\text { hyperalgesia but } \\
\text { did not induce } \\
\text { hypoalgesia. }\end{array}$ \\
\hline$[38]$ & $\begin{array}{l}\text { Male Sprague- } \\
\text { Dawley Rats }\end{array}$ & $\begin{array}{l}\text { SNI Spared Nerve } \\
\text { Injury model, sciatic } \\
\text { nerve ligation. }\end{array}$ & $\begin{array}{l}\text {-Rofecoxib: } 1 \\
\mathrm{mg} / \mathrm{kg} \\
3.2 \mathrm{mg} / \mathrm{kg}\end{array}$ & I.P. & $\begin{array}{l}\text { Group 1: } \\
3.2 \mathrm{mg} / \mathrm{kg} \text { given } \\
\text { on days } 0,1,2 \text { after } \\
\text { surgery } \\
\text { Group } 2 \text { : } \\
1 \mathrm{mg} / \mathrm{kg} \text { given on } \\
\text { days } 0,1,2,3,4,5 \text { after } \\
\text { surgery }\end{array}$ & $\begin{array}{l}\text {-Group } 1 \text { : Thermal } \\
\text { hyperalgesia and } \\
\text { allodynia monitored } \\
\text { weekly for } 54 \text { days } \\
\text { after surgery starting } \\
\text { on day } 2 \text {. } \\
\text {-Group } 2 \text { : Thermal } \\
\text { hyperalgesia and } \\
\text { allodynia measured } \\
\text { on days } 2,4 \text {, and } 10 \\
\text { after surgery. }\end{array}$ & $\begin{array}{l}\text { Rofecoxib treatment } \\
\text { failed to modify } \\
\text { the development } \\
\text { of hyperalgesia or } \\
\text { allodynia. }\end{array}$ \\
\hline$[44]$ & $\begin{array}{l}\text { Male ddY mice ages } \\
\text { 7-9 weeks }\end{array}$ & $\begin{array}{l}\text { Streptozoticin } \\
\text { induced diabetes. } \\
\text { Sciatic nerve ligation } \\
\text { induced neuropathic } \\
\text { pain. Stetlzer model. }\end{array}$ & $\begin{array}{l}\text {-Meloxicam I.P. } \\
\text { 3,10, } 30 \mathrm{mg} / \mathrm{kg} \\
\text {-Meloxicam I.T. } \\
\text { 10,30 } \mu \text { g/animal } \\
\text {-Meloxicam P.I. } 3 \mathrm{mM} \\
\text {-Ibuprofen I.P. } 30 \\
\mathrm{mg} / \mathrm{kg} .\end{array}$ & $\begin{array}{l}\text { Meloxicam IP, IT } \\
\text { and PI. } \\
\text { Ibuprofen IP. }\end{array}$ & $\begin{array}{l}\text { Drug administration } \\
\text { was done } 14 \text { days } \\
\text { after } \\
\text { Streptozoticin } \\
\text { injection, and } 7 \text { days } \\
\text { after sciatic nerve } \\
\text { ligation in mice } \\
\text { exhibiting allodynia. }\end{array}$ & $\begin{array}{l}\text { Allodynia assessed } \\
\text { for } 120 \text { minutes after } \\
\text { drug treatment in } \\
15 \text {-minute intervals } \\
\text { starting } 30 \text { before } \\
\text { drug administration. }\end{array}$ & $\begin{array}{l}\text { Intraperitoneal and } \\
\text { perineural injection, } \\
\text { but not intrathecal } \\
\text { injection, of } \\
\text { meloxicam to diabetic } \\
\text { mice elevated the } \\
\text { lowered threshold } \\
\text { providing an } \\
\text { antiallodynic effect. } \\
\text { Ibuprofen did } \\
\text { not show any } \\
\text { antiallodynic effect. }\end{array}$ \\
\hline$[43]$ & $\begin{array}{l}\text { Male Sprague- } \\
\text { Dawley rats }\end{array}$ & $\begin{array}{l}\text { Neuropathic pain } \\
\text { induced by chronic } \\
\text { constriction injury to } \\
\text { sciatic nerve. }\end{array}$ & $\begin{array}{ll}\text {-Ibuprofen } & 40 \\
\mathrm{mg} / \mathrm{kg} & \\
\text {-Celecoxib } & 30 \\
\mathrm{mg} / \mathrm{kg} & \end{array}$ & O.G. & $\begin{array}{l}\text { Drugs administered } \\
\text { daily 3-14 days after } \\
\text { surgery. }\end{array}$ & $\begin{array}{l}\text { Allodynia and } \\
\text { thermal hyperalgesia } \\
\text { were assessed on } \\
\text { days } 3 \text {, } \\
5,7,10 \text { and } 14 \text { after } \\
\text { surgery. }\end{array}$ & $\begin{array}{l}\text { Allodynia and } \\
\text { thermal hyperalgesia } \\
\text { attenuated by } \\
\text { celecoxib on days } \\
5-14 \text { after surgery } \\
\text { while ibuprofen only } \\
\text { had this effect on days } \\
7-14 \text { after surgery. }\end{array}$ \\
\hline$[41]$ & Male Sprague-Dawle & y Rats & Carrageenan induced & Hyperalgesia & $\begin{array}{l}\text {-Celecoxib } \\
7 \mathrm{mg} / \mathrm{kg} \\
\text {-Nimisulide } \quad 5 \\
\text {-Aceclofenac } 5 \mathrm{mg} / \mathbf{k g} \\
\text {-Ibuprofen } \quad 40 \mathrm{mg} \\
\text {-Indomethacin } 10 \mathrm{mg} /\end{array}$ & $\begin{array}{l}\mathrm{mg} / \mathrm{kg} \\
\mathrm{g} / \mathrm{kg} \\
\mathrm{g} / \mathrm{kg}\end{array}$ & I.P. \\
\hline$[42]$ & Adult male Wistar Rat & & $\begin{array}{l}\text { Streptozotocin induced } \\
\text { Hyperalgesia tested usir }\end{array}$ & $\begin{array}{l}\text { diabetes. } \\
\text { ing } .5 \% \text { Formalin test. }\end{array}$ & -Celecoxib: & $.3,3,10,30 \mathrm{mg} / \mathrm{kg}$ & Oral \\
\hline
\end{tabular}


Central Nervous System

\begin{tabular}{|c|c|c|c|c|}
\hline [46] & Male Harlan Sprague Dawley Rats & Allodynia induced by L5-L6 nerve ligation. & -Indomethacin: $100,200,300 \mu \mathrm{g}$ & I.T. \\
\hline [49] & Male Sprague Dawley rats & L5 single spinal nerve ligation injury. & -Meloxicam: $1,2,4, \mathrm{mg} / \mathrm{kg}$ & I.P. \\
\hline [32] & Male Sprague Dawley Rats & $\begin{array}{l}\text { L5-L6 spinal nerve ligation done to induce } \\
\text { neuropathic pain. }\end{array}$ & $\begin{array}{l}\text {-Meloxicam: } 320 \mu \mathrm{g} / \mathrm{kg} \text { per day I.T. } \\
\text {-Meloxicam: } \quad 16 \mathrm{mg} / \mathrm{kg} \text { I.P. }\end{array}$ & $\begin{array}{l}\text { I.T. via osmotic } \\
\text { pumps } \\
\text { I.P. }\end{array}$ \\
\hline [45] & Female Sprague Dawley rats & $\begin{array}{l}\text { T9-T8 laminectomy. T8 spinal cord } \\
\text { contusion performed with } 100 \text { kilodyne force }\end{array}$ & -Ibuprofen: & Subcutaneously (SC) \\
\hline
\end{tabular}

Using physically-induced peripheral nerve injury by sciatic nerve ligation in diabetic rats, it was shown that IP administered Ibuprofen (given daily for 7 days after injury) did not demonstrate any antiallodynic effects [45]. In a similar study by Wang et al. $2010,40 \mathrm{mg} /$ $\mathrm{kg}$ Ibuprofen (given daily from days 3-14 after injury) administered orally to rats subjected to chronic constriction injury of the sciatic nerve attenuated hyperalgesia and allodynia on days 7-14 after injury [43]. However, selective COX-2 inhibitor celecoxib used in the same study attenuated hyperalgesia and allodynia earlier (days 5-14) than ibuprofen suggesting it has a higher efficacy in the treatment of neuropathic pain [43].

In a SCI model the efficacy of Ibuprofen $(60 \mathrm{mg} / \mathrm{kg}$ administered 2 times day for 42 days) resulted in alleviating mechanical hyperalgesia after T8 spinal cord contusion [44]. Ibuprofen reduced levels of mechanical hyperalgesia but failed to improve locomotion. This study concluded that although ibuprofen did reduce microglia activity and early neuroinflammation, it did not produce long-term neuroprotection [44]. In central nerve injury model, following a L5-L6 spinal nerve ligation of rats, administered with indomethacin intrathecally either 1 hour, 1 day or 2 weeks, attenuated allodynia, however, treatment two weeks after injury had no effect on established allodynia. From this study, it was concluded that COX-2 is involved in the early induction of tactile allodynia but not in its maintenance in a neuropathic pain model using spinal nerve ligation [46].

Overall review of non-selective COX inhibitors has demonstrated that although these inhibitors may show potential therapeutic value, their ability to alleviate $\mathrm{NP}$ is limited comparison with more selective COX-2 inhibitors. This agrees with our current findings, as indomethacin was less effective in reducing thermal hyperalgesia when compared to celecoxib.

\section{Study 2: Meloxicam}

The predicted outcome of the study was that rats receiving meloxicam would display a decrease in NP behavior. Animals receiving the higher dose of meloxicam expected to have withdrawal latency times at or near the baseline times by day 42 post-injury. Animals receiving the lower doses expected to have higher latency times than the control rats, but not as high as the high dose. The control rats expected to have latency times below the baseline. This would confirm that Meloxicam does inhibit COX-2 expression that SCI induces upregulation of COX-2 and that up regulation of COX-2 related to the development of neuropathic pain.

Meloxicam administered intraperitoneally current findings: The nonselective COX inhibitor, meloxicam, reported to show preference for COX-2 inhibition [29]. Rats treated with $1 \mathrm{mg} / \mathrm{kg}$ meloxicam i.p. showed WLT significantly decreased from saline WLT on day 21. Rats given $2 \mathrm{mg} / \mathrm{kg}$ meloxicam i.p. had WLT significantly decreased from saline WLT on Days 21, 28, and 35. WLT in animals given 4 $\mathrm{mg} / \mathrm{kg}$ meloxicam i.p. significantly decreased from saline WLT on Days 21 and 28 (Figures 3A-3C). Meloxicam-induced decreases in
WLT unexpectedly appears to be the result of lowering hyperalgesia threshold and increasing the incidence of pain. The average percent of rats exhibiting thermal hyperalgesia from days $21,28,35$, and 42 for saline, $1 \mathrm{mg} / \mathrm{kg}, 2 \mathrm{mg} / \mathrm{kg}, 4 \mathrm{mg} / \mathrm{kg}$ of meloxicam i.p. are $28.8,41.8$, 54.6 , and $59.4 \%$ respectively (Figure $4 \mathrm{~A}$ ). Additionally the percentage mortality in saline control, $1 \mathrm{mg} / \mathrm{kg}, 2 \mathrm{mg} / \mathrm{kg}$ and $4 \mathrm{mg} / \mathrm{kg}$ meloxicam i.p. was $0.0,14.3,47.6$ and 61.9, respectively (Figure $4 \mathrm{~B}$ ). This data indicates that meloxicam i.p. caused a dose-dependent increase in both TH development and mortality in rats within the cSCI model. This suggests that meloxicam i.p. administration may be causing toxicity and that the effective therapeutic dose is less than $1 \mathrm{mg} / \mathrm{kg}$ requiring further research into the dosage and route of drug administration within this model. Possible evidence of this toxicity can be seen in the histopathology report of 2 rats treated with $4 \mathrm{mg} / \mathrm{kg}$ meloxicam IP (Table 4).

Meloxicam administered intrathecally current findings: Meloxicam administered IT resulted in mortality of $50 \%, 70 \%$ and $70 \%$ in $30 \mu \mathrm{g} / \mathrm{kg} /$ day meloxicam, $300 \mu \mathrm{g} / \mathrm{kg} /$ day meloxicam and saline group, respectively. Mortality in the control group demonstrated the experimental problems of intrathecal pumps installed in the contused rats. Among the animals that completed the study, both low-dose and high-dose meloxicam treatment was associated with a reduced rate of development of hyperalgesia (30\% low-dose vs. 33\% high-dose $v s$. $66 \%$ in saline). Across animals that exhibited hyperalgesia, low-dose meloxicam treatment transiently reduced the severity of hyperalgesia, but this effect did not persist through day 42. Across animals not exhibiting hyperalgesia, meloxicam treatment prevented a progressive desensitization observed in the saline group. However, none of the observed differences reached statistical significance. Although COX-2 inhibitors used in these studies have potential as therapeutic agent, rat mortality observed in different experimental groups limits their use in our rat model of contusion SCI and neuropathic pain.

Meloxicam and mortality current findings: Data obtained from surviving animals suggests that meloxicam may have a protective effect against the development of NP following acute SCI. However, none of the observed differences were statistically significant due to sample size of surviving rat populations in different treatments. Additionally, the high mortality observed precludes confident inference from the obtained data. It may also be possible that COX-2 inhibition impedes recovery in some ways through the loss of beneficial inflammatory effects. Furthermore, the balance between the effect of meloxicam on beneficial and destructive inflammatory processes may be dosedependent. The observation of high mortality in all experimental groups may indicate an underlying inadequacy of the experimental model rather than an effect of meloxicam administration. Based on previous experiments, we believe that the high mortality is primarily due to the placement of the IT catheter. Similar studies performed in our laboratory that did not include IT catheter placement produced minimal mortality. The choice of IT drug delivery made to maximize penetration of the drug to the injury site and to minimize systemic drug effects. However, the use of alternative drug delivery methods in future 
studies may yield better outcomes. It is also important to note that this study performed in a rat model. It is becoming increasingly evident that the development of NP exhibits substantial species and even strain dependence. Therefore, data obtained from this model may not be entirely applicable to the true human clinical situation.

Meloxicam in nerve damage models: The COX-2 inhibitor meloxicam considered an effective non-steroidal anti-inflammatory drug (NSAID), a strong inhibitor of COX with selectivity for COX-2 and possessing a good gastro-intestinal tolerability $[47,48]$. Meloxicam has shown to provide similar anti-inflammatory and analgesic effects as that of nonselective NSAIDs but with a lower gastrointestinal bleeding risk and less effect on platelet aggregation [38]. In past studies using an animal model, the efficacy of Meloxicam, a non- selective COX inhibitor with selectivity for COX-2, reported in physically- and chemically-induced nerve injury of both the peripheral and central nervous system.

Diabetic mice in a peripheral neuropathic pain model where sciatic nerve was ligated were treated with meloxicam either i.p, i.t. or perineural injection for 7 days after nerve ligation [44]. Meloxicam i.p. and p.i. injections, but not i.t. infusion elevated the lowered threshold and produced an antiallodynic effect in established diabetic NP mice model. These findings reveal that meloxicam acts mainly in peripheral sites to exhibit antiallodynic effects in diabetic mice with established neuropathic pain. This is evident by inability of meloxicam, administered i.t. to demonstrate elevation of the lowered threshold and corroborate our findings employing contusion SCINP (cSCINP) model of rat. Furthermore, this provides evidence that meloxicam acts both at peripheral and the spinal cord in Seltzer-model mice [44].

Meloxicam was to attenuate development and maintenance of both thermal hyperalgesia and mechanical allodynia induced by peripheral nerve injury [32]. Immediate administration of meloxicam injected i.t. acted anti-development of mechanical allodynia and $\mathrm{TH}$ induced by spinal nerve ligation (SNL) [32]. However, treatment initiated a week following ligation could not reverse established NP and glial activation. In the same study, systemically administered meloxicam $(16 \mathrm{mg} / \mathrm{kg}$ i.p.) started 7 days after ligation partially reversed NP but not glial activation. This data suggests that spinal prostaglandin production by spinal COX-2 plays a pivotal role in the development of neuropathic pain, however, it is not critical for the maintenance of such pain [32].

Systemic administration of $2 \mathrm{mg} / \mathrm{kg}$ and $4 \mathrm{mg} / \mathrm{kg}$ meloxicam injected i.p. to rats with an L5 single spinal nerve ligation exhibited antiallodynic effects [49]. Nerve-injured rats receiving repeated dosages of meloxicam (2, or $4 \mathrm{mg} / \mathrm{kg}$ ) at $0,12,24$, and 36 hours demonstrated significant increases in hind-paw withdrawal thresholds compared with those of the vehicle-treated animals [49]. Their results suggest that COX-2 may be partially involved in the development of tactile allodynia [49]. In our study, we used similar meloxicam dosages employing our well established cSCI model. However, mortality data in meloxicam-treated rats vs vehicle-injected rats was a limiting factor.

In a carrageenan induced- hyperalgesia (CCI) rat model, coadministration of amino guanidine hydrochloride( an INOS inhibitor) with meloxicam 1 hour before CCI produced a significant rise in pain threshold for mechanical hyperalgesia in the ipsilateral hind paw when compared with the groups treated with various doses of amino guanidine hydrochloride and meloxicam alone [50]. The results showed that combination of $1 \mathrm{mg} / \mathrm{kg}$ meloxicam and increasing doses of amino guanidine hydrochloride $(30,100$, and $300 \mathrm{mg} / \mathrm{kg}$ ) had a synergistic anti- inflammatory effect indicated by significant increase in paw withdrawal latencies to mechanical stimuli at early stage of $6 \mathrm{~h}$ following CCI [50]. These findings suggest that co-administration of meloxicam with amino guanidine hydrochloride may be an alternative therapeutic approach for the treatment of neuropathic pain [50].

\section{Conclusion}

Early administration of COX inhibitors showed some beneficial effects in the SCI model as discussed above. It is clear, however, that more work is necessary for the best possible treatment. Coupled with earlier studies reviewed here, particularly because of the possible adverse effects noted, it is clear that the specific nature of the initial damage to major tissues and structures contributing to the degeneration and reorganization of the nervous system are necessary. Histopathology studies of test animal necropsy appear necessary to discover further the reasons behind high rates of morbidity and mortality in certain test conditions. Experimental designs aimed at isolating pre-treatment, post-treatment time line of application and changing range of doses for different COX inhibitors is required. Drug combinations or sequential delivery of agents post-injury may be necessary.

Many factors contribute to the development and maintenance of NP. However, mortality issues are coming up as limitation in optimizing the effectiveness of these therapeutic agents. Comparing our other studies using celecoxib and indomethacin inhibitors for example, use of meloxicam has a potential for its use if administered i.p.. We propose in vitro experiments to test the effect of various dosages of the COX inhibitors using cell culture of spinal cord tissue or dorsal root ganglion to rule out mortality data. Yet, none of our in vivo findings on contusion SCINP rat model has gone for clinical trial. Even promising studies in the past including passive or active immunization with myelin basic protein promotes recovery from $\mathrm{CSCI}$ [48] and further improvement in the impaired neurological function after SCI in laboratory experimental rats [49] could not yield successful results in clinical trials. It is clear that although progress in treatment made, however, more variables need to study for clarifying the efficacy of used COX inhibitors in the prevention of chronic pain development following cSCI (Table 5).

\section{Acknowledgements}

Support for this study provided by Herman and Gwendolyn Shapiro Foundation, Department of Neurological Surgery, University of Wisconsin School of Medicine and Public Health, Congress of Neurological Surgeons Synthes Spine Fellowship Award, National Science Foundation, University of Wisconsin-Madison Graduate School McNair Scholars Program. Also, the project was supported by the Clinical and Translational Science Award (CTSA) program, through the NIH National Center for Advancing Translational Sciences (NCATS), grant UL1TR000427. The content is solely the responsibility of the authors and does not necessarily represent the official views of the NIH. Contributions to the writing of this manuscript also made by Kristen Obiakor BS, Clayton Sweeney BS, John H. Cain MD, Christopher Baggott, MD, Michael Boison MD, and Jessica Tilghman BS.

\section{Authors' contribution}

Experiments designed by GSM and experimental help by undergraduate and medical students $\mathrm{MB}, \mathrm{JHC}, \mathrm{CB}, \mathrm{CS}, \mathrm{JT}$, and $\mathrm{KO}$. Lab facilities/reagents and materials/analysis tools were provided by DKR. Data analysis performed by ES. The manuscript including original data and COX inhibitors' review written by GSM, SO, and PM. 


\section{Ethical approval}

The protocol and all surgical procedures were in accordance with NIH guidelines and approved by the UW Institutional Animal Use and Care Committee (ACUC).

\section{References}

1. Finnerup NB, Johannesen IL, Sindrup SH, Bach FW, Jensen TS (2001) Pain and dysesthesia in patients with spinal cord injury: A postal survey. Spinal Cord 39: 256262. [Crossref]

2. Finnerup NB, Jensen TS (2004) Spinal cord injury pain--mechanisms and treatment. Eur J Neurol 11: 73-82. [Crossref]

3. Finnerup NB, Sindrup SH, Jensen TS (2007) Chronic neuropathic pain: mechanisms, drug targets and measurement. Fundam Clin Pharmacol 21: 129-136. [Crossref]

4. Barrett H, McClelland JM, Rutkowski SB, Siddall PJ (2003) Pain characteristics in patients admitted to hospital with complications after spinal cord injury. Arch Phys Med Rehabil 84: 187-197. [Crossref]

5. Siddall PJ, McClelland JM, Rutkowski SB, Cousins MJ (2003) A longitudinal study of the prevalence and characteristics of pain in the first 5 years following spinal cord injury. Pain 103: 249-257. [Crossref]

6. Siddall PJ, Taylor DA, Cousins MJ (1997) Classification of pain following spinal cord injury. Spinal Cord 35: 69-75. [Crossref]

7. Resnick DK, Graham SH, Dixon CE, Marion DW (1998) Role of cyclooxygenase 2 in acute spinal cord injury. $J$ Neurotrauma 15: 1005-1013. [Crossref]

8. Schomberg D, Ahmed M, Miranpuri G, Olson J, Resnick DK (2012) Neuropathic pain: role of inflammation, immune response, and ion channel activity in central injury mechanisms. Ann Neurosci 19: 125-132. [Crossref]

9. Park SW, Yi JH, Miranpuri G, Satriotomo I, Bowen K, et al. (2007) Thiazolidinedione class of peroxisome proliferator-activated receptor gamma agonists prevents neuronal damage, motor dysfunction, myelin loss, neuropathic pain, and inflammation after spinal cord injury in adult rats. J Pharmacol Exp Ther 320: 1002-1012. [Crossref]

10. Tilghman J, Miranpuri GS, Resnick D, Cain J, Baggott C, et al. (2007) The effect of cyclooxygenase 2 inhibitor Meloxicam on neuropathic pain following spinal cord injury. IBS-SRP Research Journal: 111-114.

11. Cain JH, Baggott C, Tilghman JI, Rajpal S, Miranpuri GS, et al. (2007) Recent developments in the study of spinal cord injury and neuropathic pain. Annals of Neurosciences 14: 96-107.

12. Rajpal S, Gerovac TA, Turner NA, Tilghman JI, Allcock BK, et al. (2007) Antihyperalgesic effects of vanilloid-1 and bradykinin-1 receptor antagonists following spinal cord injury in rats. J Neurosurg Spine 6: 420-424. [Crossref]

13. Rajpal S, Steinmetz MP, Cheema AA, Seebruck CJ, Gerovac TA, et al. (2008) Effect of delayed rolipram on thermal hyperalgesia following spinal cord injury. Annals of Neurosciences 15: 27-30.

14. Ahmed MM, Rajpal S, Sweeney C, Gerovac TA, Allcock B, et al. (2010) Cannabinoid subtype-2 receptors modulate the antihyperalgesic effect of WIN 55,212-2 in rats with neuropathic spinal cord injury pain. Spine J 10: 1049-1054. [Crossref]

15. Cramer SW, Baggott C, Cain J, Tilghman J, Allcock B, et al. (2008) The role of cationdependent chloride transporters in neuropathic pain following spinal cord injury. Mol Pain 4: 36. [Crossref]

16. Hasbargen T, Ahmed MM, Miranpuri G, Li L, Kahle KT, et al. (2010) Role of NKCC1 and $\mathrm{KCC} 2$ in the development of chronic neuropathic pain following spinal cord injury. Ann N Y Acad Sci 1198: 168-172. [Crossref]

17. Lee HK, Ahmed MM, King KC, Miranpuri GS, Kahle KT, et al. (2014) Persistent phosphorylation of NKCC1 and WNK1 in the epicenter of the spinal cord following contusion injury. Spine J 14: 777-781. [Crossref]

18. Ahmed MM, Lee H, Clark Z, Miranpuri GS, Nacht C, et al. (2014) Pathogenesis of spinal cord injury induced edema and neuropathic pain: expression of multiple isoforms of wnk1. Ann Neurosci 21: 97-103. [Crossref]

19. Tegeder I, Niederberger E, Vetter G, Bräutigam L, Geisslinger G (2001) Effects of selective COX-1 and -2 inhibition on formalin-evoked nociceptive behaviour and prostaglandin E(2) release in the spinal cord. J Neurochem 79: 777-786. [Crossref]

20. Minami T, Okuda-Ashitaka E, Hori Y, Sakuma S, Sugimoto T, et al. (1999) Involvement of primary afferent $\mathrm{C}$-fibres in touch-evoked pain (allodynia) induced by prostaglandin E2. Eur J Neurosci 11: 1849-1856. [Crossref]
21. Hains BC, Yucra JA, Hulsebosch CE (2001) Reduction of pathological and behavioral deficits following spinal cord contusion injury with the selective cyclooxygenase-2 inhibitor NS-398. J Neurotrauma 18: 409-423. [Crossref]

22. Schäfers M, Marziniak M, Sorkin LS, Yaksh TL, Sommer C. (2004) Cyclooxygenase inhibition in nerve injury and TNF-induced hyperalgesia in the rat. Exp Neurol 185 160-168. [Crossref]

23. Hara K, Kong DL, Sharp FR, Weinstein PR (1998) Effect of selective inhibition of cyclooxygenase 2 on temporary focal cerebral ischemia in rats. Neurosci Lett 256: 5356. [Crossref]

24. Mitsuhashi M, Liu J, Cao S, Shi X, Ma X (2004) Regulation of interleukin-12 gene expression and its anti-tumor activities by prostaglandin E2 derived from mammary carcinomas. J Leukoc Biol 76: 322-332. [Crossref]

25. Everts B, Währborg P, Hedner T (2000) COX-2-Specific inhibitors--the emergence of a new class of analgesic and anti-inflammatory drugs. Clin Rheumatol 19: 331-343. [Crossref]

26. Bombardier C (2002) An evidence-based evaluation of the gastrointestinal safety of coxibs. Am J Cardiol 89: 3D-9D. [Crossref]

27. Penning TD, Talley JJ, Bertenshaw SR, Carter JS, Collins PW, et al. (1997) Synthesis and biological evaluation of the 1,5-diarylpyrazole class of cyclooxygenase-2 inhibitors: identification of 4-[5-(4-methylphenyl)-3-(trifluoromethyl)-1H-pyrazol-1yl]benze nesulfonamide (SC-58635, celecoxib). J Med Chem 40: 1347-1365. [Crossref]

28. Dirig DM, Isakson PC, Yaksh TL (1998) Effect of COX-1 and COX-2 inhibition on induction and maintenance of carrageenan-evoked thermal hyperalgesia in rats. $J$ Pharmacol Exp Ther 285: 1031-1038. [Crossref]

29. Kato M, Nishida S, Kitasato H, Sakata N, Kawai S (2001) Cyclooxygenase-1 and cyclooxygenase-2 selectivity of non-steroidal anti-inflammatory drugs: investigation using human peripheral monocytes. J Pharm Pharmacol 53: 1679-1685. [Crossref]

30. Francischi JN, Chaves CT, Moura AC, Lima AS, Rocha OA, et al. (2002) Selective inhibitors of cyclo-oxygenase-2 (COX-2) induce hypoalgesia in a rat paw model of inflammation. Br J Pharmacol 137: 837-44. [Crossref]

31. Meloxicam JG (2010) Cambridge University Press Online ISBN: 9780511841378 Chapter [DOI: http://dx.doi.org/10.1017/CBO9780511841378.059] Anesthesia Intensive Care, Pain Management: 249-251.

32. Takeda K, Sawamura S, Tamai H, Sekiyama H, Hanaoka K (2005) Role for cyclooxygenase 2 in the development and maintenance of neuropathic pain and spinal glial activation. Anesthesiology 103: 837-844. [Crossref]

33. Takeda K, Sawamura S, Tamai H, Sekiyama H, Hanaoka K (2005) Role for cyclooxygenase 2 in the development and maintenance of neuropathic pain and spinal glial activation. Anesthesiology 103: 837-844. [Crossref]

34. Hakan T, Toklu HZ, Biber N, Celik H, Erzik C, et al. (2011) Meloxicam exerts neuroprotection on spinal cord trauma in rats. Int J Neurosci 121: 142-148. [Crossref]

35. Resnick DK, Schmitt C, Miranpuri GS, Dhodda VK, Isaacson J, et al. (2004) Molecular evidence of repair and plasticity following spinal cord injury. Neuroreport 15: 837-839. [Crossref]

36. Schmitt C, Miranpuri GS, Dhodda VK, Isaacson J, Vemuganti R, et al. (2006) Changes in spinal cord injury-induced gene expression in rat are strain-dependent. Spine $J 6$ : 113-119. [Crossref]

37. DomBourian MG, Turner NA, Gerovac TA, Vemuganti R, Miranpuri GS, et al. (2006) B1 and TRPV-1 receptor genes and their relationship to hyperalgesia following spinal cord injury. Spine (Phila Pa 1976). 2006; 15;31(24):2778-82. [Crossref]

38. Kim HT, Kim T, Novotny B, Khan N, Aksamit J, et al. (2014) Thermal hyperalgesia assessment for rats after spinal cord injury: developing a valid and useful pain index. Spine J 14: 984-989. [Crossref]

39. Kim HT, Kim T, Novotny B, Khan N, Aksamit J, et al. (2014) Thermal hyperalgesia assessment for rats after spinal cord injury: developing a valid and useful pain index. Spine J 14: 984-989. [Crossref]

40. Broom DC, Samad TA, Kohno T, Tegeder I, Geisslinger G, et al. (2004) Cyclooxygenase 2 expression in the spared nerve injury model of neuropathic pain. Neuroscience 124 : 891-900. [Crossref]

41. Paulson SK, Zhang JY, Breau AP, Hribar JD, Liu NW, et al. (2000) Pharmacokinetics, tissue distribution, metabolism, and excretion of celecoxib in rats. Drug Metab Dispos 28: 514-521. [Crossref]

42. Hay C, de Belleroche J (1997) Carrageenan-induced hyperalgesia is associated with increased cyclo-oxygenase-2 expression in spinal cord. Neuroreport 8: 1249-1251. [Crossref] 
43. Chopade AR, Sayyad FJ, Naikwade NS (2014) Pharmacological characterization of carrageenan induced heat muscle hyperalgesia in rats using non-selective, preferential and selective COX-2 inhibitors. Pharmacol Rep 66: 353-362. [Crossref]

44. Juarez-Rojop IE, Morales-Hernandez PE, Tovilla-Zarate CA, Bermúdez-Ocaña DY, Torres-Lopez JE, et al. (2015) Celecoxib reduces hyperalgesia and tactile allodynia in diabetic rats. Pharmacol Rep 67: 545-552. [Crossref]

45. Wang Y, Zhang X, Guo QL, Zou WY, Huang CS, et al. (2010) Cyclooxygenase inhibitors suppress the expression of $\mathrm{P} 2 \mathrm{X}(3)$ receptors in the DRG and attenuate hyperalgesia following chronic constriction injury in rats. Neurosci Lett 478: 77-81. [Crossref]

46. Redondo-Castro E, Navarro X (2014) Chronic ibuprofen administration reduces neuropathic pain but does not exert neuroprotection after spinal cord injury in adult rats. Exp Neurol 252: 95-103. [Crossref]

47. Kimura S, Kontani H (2009) Demonstration of antiallodynic effects of the cyclooxygenase-2 inhibitor meloxicam on established diabetic neuropathic pain in mice. J Pharmacol Sci 110: 213-217. [Crossref]
48. Zhao Z, Chen SR, Eisenach JC, Busija DW, Pan HL (2000) Spinal cyclooxygenase-2 is involved in development of allodynia after nerve injury in rats. Neuroscience 97 : 743-748. [Crossref]

49. Engelhardt G, Bogel R, Schnitzeler C, Utzmann R (1996) Meloxicam: influence on arachidonic acid metabolism. Part 1. In vitro findings. Biochem Pharmacol 51: 21-28. [Crossref]

50. Turck D, Busch U, Heinzel G, Narjes H (1997) Clinical pharmacokinetics of meloxicam. Arzneimittelforschung 47: 253-258. [Crossref]

51. Takahashi M, Kawaguchi M, Shimada K, Nakashima T, Furuya H (2005) Systemic meloxicam reduces tactile allodynia development after L5 single spinal nerve injury in rats. Reg Anesth Pain Med 30: 351-355.

52. Dudhgaonkar SP, Tandan SK, Bhat AS, Jadhav SH, Kumar D (2006) Synergistic antiinflammatory interaction between meloxicam and aminoguanidine hydrochloride in carrageenan-induced acute inflammation in rats. Life Sci 78: 1044-1048. [Crossref]

Copyright: $\odot 2017$ Moran PM. This is an open-access article distributed under the terms of the Creative Commons Attribution License, which permits unrestricted use, distribution, and reproduction in any medium, provided the original author and source are credited. 